AndŻELIKA KuŹNAR

Warsaw School of Economics, Poland

JOANNA ŻUKOWSKA

Warsaw School of Economics, Poland

\title{
Benefits Resulting from Maintaining a Relationship between Economic Universities and Their Alumni: the Case of the Warsaw School of Economics
}

\begin{abstract}
Alumni are more and more often perceived as the most important asset of a university, crucial for the implementation of its strategic goals. Polish economic universities, in comparison to American and many European ones, have much to catch up on in this area. The problem is not only that funds are too small in relation to the needs. There is a lack of systematised knowledge about the possible benefits of maintaining a relationship between universities and alumni, as well as the lack of developed models for this cooperation. The aim of the article is to assess the benefits of cooperation between universities of economics and their alumni taking into account the benefits for the university, its alumni and present students, and to identify good practice in this area. The research method was based on the analysis of the results of a survey conducted online from 28 universities in 19 countries. An additional source of information was the literature, websites, a diagnosis of the situation at the Warsaw School of Economics (SGH) and the experience of the authors who have visited some of the foreign universities. As a result of the analysis, it was found that universities are aware of the benefits of maintaining relationships with alumni. The quality of this cooperation is not satisfactory and action is necessary to organise it better. In the case of the SGH, which has been subject to a detailed analysis, there is no clear definition of the goals for maintaining relationships with alumni. The priority should be to develop a long-term strategy leading to organising these relations and outline a desired model of cooperation.
\end{abstract}

Keywords: alumni; friend-raising; fundraising; good practice; university

Received: 10 September 2019

Accepted: 18 May 2020

\section{Suggested citation:}

Kuźnar, A., Żukowska, J. (2020). Benefits Resulting from Maintaining a Relationship between Economic Universities and Their Alumni: the Case of the Warsaw School of Economics. Przedsiębiorczość - Edukacja [Entrepreneurship - Education], 16(1), 95-105. doi: 10.24917/20833296.161.8

\section{Introduction}

Competing for the best candidates means that the most prestigious universities, wishing to stand out in the education market, treat relations with alumni as a strategic area of 
their activity. The fact that alumni are one of the greatest strengths of universities, key factors in the implementation of their mission and strategic goals ${ }^{1}$, are frequently repeated (Hashim, Kee, Rahman ${ }^{2}$, 2014; Levine, 2008; Łazorko, 2016). However, it is not always possible to go beyond this. One of the main barriers which make real and valuable relationships between universities and alumni difficult to achieve is the lack of a developed model for cooperation in this area. Such a statement appears in one of the few studies devoted to university-student-graduate relations in Poland, conducted as part of the ideAGORA project (Diagnoza..., 2013).

The aim here is to assess the benefits of cooperation between universities and alumni and identify good practice in this field. The demand for such research was reported in 2017 by the Warsaw School of Economics (SGH) which announced a competition for a 'Rector's Grant' on this topic. This article summarises the part of broader results of research carried out at the Warsaw School of Economics, therefore the recommendations focus on this university, but they could be the basis for activities at other economic universities in Poland. The benefits for universities, alumni and students are all presented but the obstacles that hinder cooperation are identified too. Empirical verification of the following hypotheses are made:

- universities and students need relationships with alumni,

- alumni need relationships with the university, other alumni and students.

The article has five parts. The first three are devoted to the benefits of cooperation between universities and alumni in the following order: universities, alumni, students; the factors that support the cooperation are reviewed. Part four concentrates on obstacles that impede cooperation. Part five contains conclusions and recommendations.

\section{Research methods}

The analysis of models of cooperation between universities and alumni was based on the results of an online survey conducted between 22 August and 20 September 2017, directed to Warsaw School of Economics' partner universities. The survey contained 18 questions, including half-closed and half-open ones. Additional sources of information were literature, websites, a diagnosis of the situation at the Warsaw School of Economics and the experience of the authors who had visited some of the examined colleges in the past.

Full answers were given by respondents from 28 universities, representing 19 countries from around the world ${ }^{3}$. No universities from the United States were invited to participate because of the non-transferability of the American experience to European conditions, in particular Polish. There are many reasons for this, but they can be divided into three main groups: organisational (institutional), cultural and financial.

1 The tangible proof of the strategic importance of alumni for universities is the fact that obtaining many accreditations depends on including relations with alumni into the development strategy (as in the case of AMBA, Equis, AACSB).

2 "Colleges and universities proactively try to 'cultivate and retain the loyalty and support of continuing assistance $[\ldots]$ institutions of higher education need allies and supporters; and they rely on their alumni to play this role"' (Muller, 1986: 7).

3 Belgium, Brazil, Cyprus, Estonia, Finland, France, Spain, Israel, Japan, Canada, South Korea, Germany, Peru, Poland, Romania, Slovenia, Sweden, Taiwan, Italy. 
Firstly, in Europe, except the UK, fundraising departments rarely operate in universities or they consist of just a small team. This is partly due to the reluctance to invest in such activities and the fact that there are no employees with appropriate qualifications. Unlike the United States, where professional fundraising has a long tradition, it is difficult for European institutions to find people with the qualifications necessary to perform effective fundraising. Secondly, there are cultural differences between a citizen's approach to donating funds for charity and making donations sponsoring various types of institutions (Murray, no date; Pérez-Esparrells, Torre, 2012). The basic factor, internally differentiating models of the socio-economic system in the liberal market economy for continental and Anglo-Saxon variants, is the scale of the involvement of state institutions in the implementation of internal functions of the state. In the continental tradition, the state replaced the feudal ruler for the sake of its citizens, while in the Anglo-Saxon tradition, citizens take care of themselves. In many European countries, there is a perception that the government is responsible for financing culture and education. On the European continent, since the $16^{\text {th }}$ century, universities have been financed by the state. At the beginning of the $20^{\text {th }}$ century, significant private universities were founded ${ }^{4}$, followed by their intensive development at the turn of the $20^{\text {th }}$ and $21^{\text {st }}$ centuries. On the other hand, state-funded universities were not only uninterested in raising funds from private sources, but also governments were legally limiting these possibilities, assuming that the financing of universities was under their control. In the USA, however, educational and cultural institutions were created primarily from private funds. The founders established the most important institutions of this type in the USA and donations gave rise to the tradition of financing universities from non-public sources.

The continental model is firmly rooted in Poland, where after World War II the only university supported by private donations was the Catholic University in Lublin (its legal status was changed in the last decade of the $20^{\text {th }}$ century). The weakness of patterns and practice before 1917 and from 1945 to 1989 hindered creating deeper university-student-graduate ties. Thirdly, the continental and Anglo-Saxon models are differentiated by tax considerations. For example, in the case of planned donations, a subject declaring it to be granted to a non-profit organisation or foundation, receives tax relief realised at the time of donation, but until then the capital is allowed to be used (Murray, no date). In some European countries, universities are treated as budgetary units as in the Polish legal system. This means, for example, that all donations go to the treasury.

\section{Benefits for the university}

In universities, there is a justified belief that alumni can be a source of support in carrying out their tasks. Although creating an entire catalogue of benefits is not possible, several areas of such benefits emerge from both in the literature review and the survey. The benefits mentioned below were indicated by the respondents who were interviewed by the authors using open questions and some closed questions. Due to the length of this article, it is not possible to present all the results, so they have been summarised, pointing out the most significant ideas (Kuźnar, Żukowska, 2018).

4 In the interwar period in Poland there were three private universities including The Warsaw School of Economics SGH, while in the years 1945-1989 there was only one: Catholic University of Lublin (KUL). 
First of all, it is emphasised that alumni can be very helpful in recruiting candidates. They are advocates for the university and are extremely credible. Enthusiastic opinions about the university they graduated from are reliable and say more than dry facts cited by the staff (Feudi, Clifford, 2002). Word of mouth marketing is one of the most important ways to reach potential students (Kamiński, 2014) and alumni can play a particularly important role in recruiting students from abroad. Limited funds mean that universities cannot always afford to hire professional recruiters and in such a situation, it is worth reaching for the help of alumni living abroad.

Successful alumni are also a showcase for the university, a practical proof of the quality of its education. This is one of the reasons why universities seek interviews with famous alumni, publish information about their successes, and make lists of those who play an important role in politics, science, economy, sport, and culture ${ }^{5}$. Alumni are often recognised as the most loyal followers and best ambassadors, offering invaluable marketing and promotion through personal and professional networks (Cannon, 2015). These graduate-ambassadors create the university's reputation which is largely based on their successes (Cannon, 2015). Some colleges even create programmes in which alumni are formally awarded the title of the ambassador.

Alumni can make a significant contribution to creating and sharing knowledge with students (improving the quality of teaching) and academics (providing them with research areas) (Łazorko, 2016), participating in joint research projects and helping to commercialise research (Bryła, Jurczyk, Domański, 2013). In many universities, alumni are invited to give lectures, contributing to the content and adapting it to the requirements of the labour market. At the Warsaw School of Economics, due to extensive contacts with businesses, alumni appear as lecturers and trainers both as part of formal cooperation (e.g. the postgraduate studies programs ${ }^{6}$ ), and are guests of individual lecturers in some classes. It is a valuable source of additional knowledge for students and an opportunity to exchange experiences.

Alumni are also a source of university co-financing. This thread of cooperation dominates the Anglo-Saxon research (Daly, 2013; Harrison, 1995; Levine, 2008; Meer, Rosen, 2012; Stevick, 2010) where the role of the graduate as a potential donor is emphasised. Obtaining financial support from alumni is the main goal of many American universities. This is favoured by legal solutions (tax breaks) and culture (the "giving back" tradition ${ }^{7}$ ), which is not repeated in continental Europe. Tax relief systems related to philanthropic activities which are donations for universities are found in many countries. However, in the USA less often than in Europe, these actions are justified using both moral and accounting reasons (even the term "philanthrocapitalism" has been coined of this phenomenon) (Tett, 2012).

The results of the survey indicate that universities rarely ask alumni for financial support (see Figure 1).

5 Such information can be found e.g. on the websites of SGH-The Warsaw School of Economics, Krakow University of Economics, Nicolas Copernicus University in Torun, Kozminski University.

6 Studiuj praktycznie (2018).

7 "Giving back" includes not only financial subsidies, though we pay attention to this aspect here. It could also comprise sharing time, knowledge and experience, etc. 
Figure 1. Survey question: Are alumni asked for financial support by universities or students?

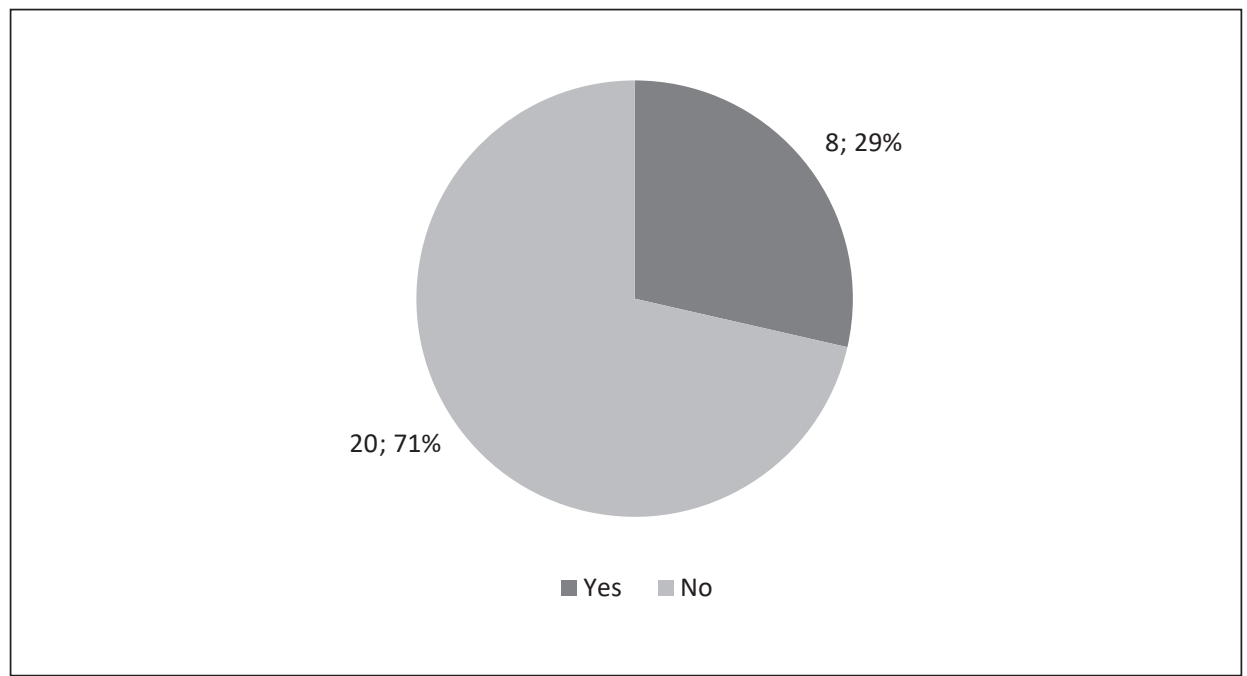

Source: author

The above result is also consistent with the answer to another question regarding the best way to describe the purpose of maintaining relations with alumni by the university. Sixty-one per cent of the respondents pointed to "friend-raising", i.e. building relationships based on social contacts, while $36 \%$ pointed to both goals. However, no one indicated the mere raising of funds as the main goal of a university's cooperation with alumni (see Figure 2).

Figure 2. Survey question: Which word describes the purpose of a university's relationship with alumni best?

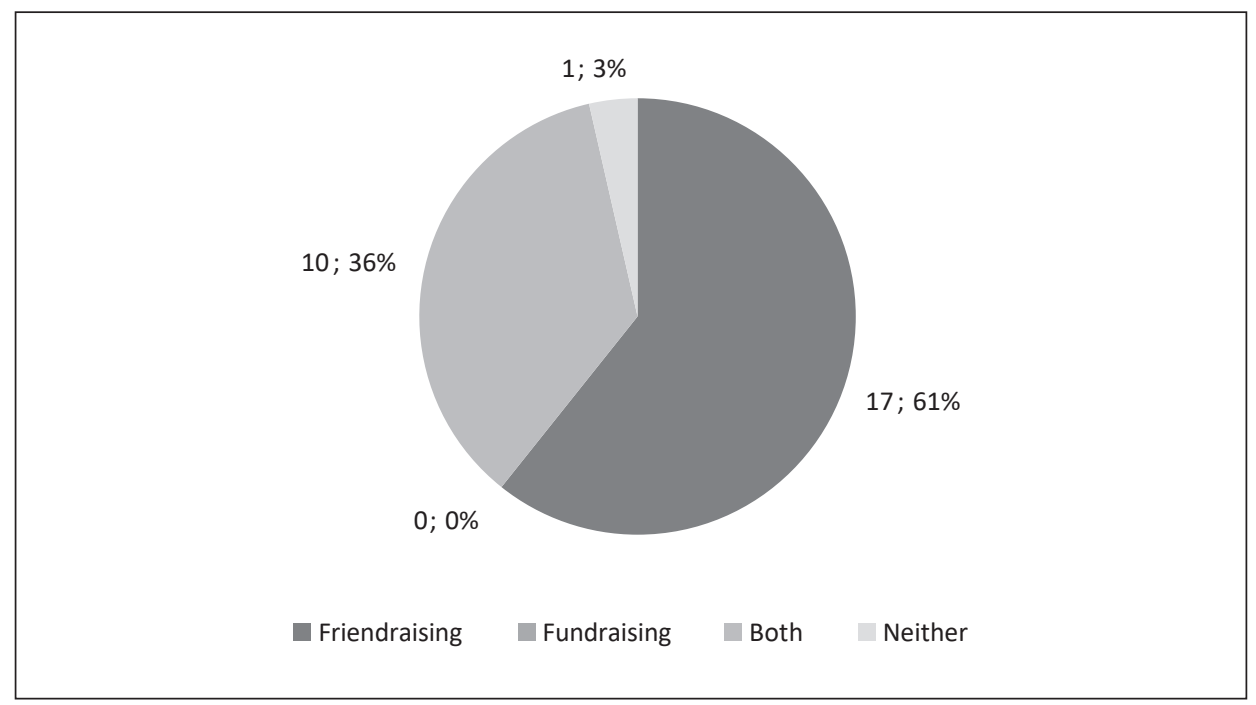

Source: author 
Benefits for alumni

Obtaining the above mentioned benefits by universities from relations with alumni is largely conditioned by sending an attractive offer to them. This means the necessity of identifying their needs, developing responses and appropriate communication.

The survey shows that universities have a fairly extensive catalogue of benefits that they offer to alumni. These may include (Kuźnar, Żukowska, 2018):

- access to discounts and rebates, e.g. for the purchase of books, language learning, theatre tickets, etc.;

- access to 'open training', which is a collection of archived recordings of lectures, magazines, notes;

- the possibility of using libraries and subscribed electronic databases;

- access to campus infrastructure, e.g. a gym, a swimming pool, lecture halls for meetings of class;

- an electronic mail with a university address;

- maintaining contact with a network of specialists, e.g. by participating in conferences held at the university;

- the ability to share knowledge;

- enriching one's personal and professional skills;

- opportunity to develop one's career;

- participation in educational programs co-created by the university and companies cooperating with it;

- access to the latest research results;

- opportunity to observe and recruit job candidates;

- keeping in touch with friends;

- obtaining support while organising conventions and meetings;

- pride in the university they graduated from;

- deriving satisfaction from helping younger colleagues.

These benefits can be used to help formulate appropriate action by the university that could potentially encourage alumni to cooperate. The most common programs aimed at engaging them in the life of the university and its communities include business breakfasts and dinners, meetings and conventions, graduate clubs (regional, international, functional and industry ones), a network of business angels, mentoring, lectures for students, joint development of research projects, job fairs, award ceremonies "for outstanding alumni", networking events, trips, discounts on shopping for products and services, New Year parties and other events, a graduate magazine, an online communication platform, etc. The benefits could be complemented by the opinions of the alumni themselves, however, it can be assumed that if a university's proposals produce attendance on the part of alumni, then these are activities that are justified.

\section{Benefits for students}

Students are another group that can benefit from cooperation between a university and its alumni. They gain contact with a real-world environment which could facilitate their professional lives. 
Alumni are seen as a source of job offers and internships for students. Sometimes they help students shape their professional path by participating in mentoring programs. They appear at job fairs, workshops, company presentations and meetings organised by student academic clubs. In all these places students have the opportunity to establish direct contact with their home university alumni and join their network of contacts.

Alumni provide information on possible career paths along a specific field of study, in an industry or company, or even offering internships or jobs (Bryła, Jurczyk, Domański, 2013). The respondents also indicate that students have the opportunity to familiarise themselves with business projects which also increase the students' chances on the labour market, giving them the opportunity to learn about the practical effects of their education.

Creating the culture of becoming a graduate is also important. Thanks to relationships with alumni, students are beginning to think of themselves as future alumni (Rissmeyer, 2010). In some universities (e.g. in ESADE in Spain), from the first year, the graduate association invites students to become members, offering them a package of benefits, while exempting them from membership fees or reducing the contribution. Thanks to meetings for alumni, also open to students, both groups have the opportunity to get to know each other, which gives them the chance to develop and enrich personal and professional skills. It also provides a steady inflow of new members to the alumni association.

How effectively are students reached with the right offer is proved by their active participation in meetings with alumni, in mentoring programs, as well as by the high ratings of classes led by alumni ${ }^{8}$.

\section{Limitations and sources of difficulties in maintaining relations with alumni}

Obtaining the support of alumni requires building and maintaining a stable relationship with them. Research indicates that the chances of getting alumni, including their financial support, increase if they feel emotionally connected to the university (Coll, Tsao, 2005; Levine, 2008; Parsons, Wethington, 1996). Then, the sense of relationship is positively affected by its reputation and the value of the education received, the university traditions and rituals, as well as identifying with teams which achieve success in sport or in other fields. It is also important whether the university where the graduate studied was the first choice (Levine, 2008). Universities are not able to influence all of these elements, but communication with alumni is certainly necessary to achieve success. Meanwhile, as the authors of Diagnoza... (2013) indicate: [Polish] "universities do not care about contact with alumni. They underestimate the importance and value of building such relationships with their former students. At most, they limit themselves to sending them non-personalised offers of postgraduate work, and this is even rare".

Despite the awareness of benefits, relations with alumni are not always deep; in Polish universities it is even said that they are shallow (Diagnoza, 2013: 4). There are no mechanisms to collect and use feedback from students and alumni about the quality of education, and consequently, the potential that lies in the university-graduate relationship is wasted.

\footnotetext{
${ }^{8}$ For example, on 12 March 2018 a mentoring program was launched for the final year students of undergraduate and graduate studies at the Warsaw School of Economics. http://administracja.sgh.waw.pl/pl/ckirza/ mentoring/Strony/default.aspx
} 
The respondents pointed to the reasons for this issue. According to them, the university has an insufficient number of employees responsible for maintaining contacts with alumni and there is also a lack of time and resources to carry out such activities. The study indicates that building and maintaining relationships with alumni demand the existence of a separate unit dedicated to this area. Although in most of the surveyed universities $(82 \%)$ there is a unit responsible for relations with alumni, the organisational structure is not always suited to the needs.

In the largest number of universities, there are independent "alumni departments" ( $43 \%$ of responses), in others the unit responsible for relations with alumni are included in the university's "development" departments (18\%), "career centres" (14\%), "fundraising" (7\%) and others (e.g. marketing department, general affairs) ${ }^{9}$ - see Figure 3.

It would be more effective if a separate unit existed because it would allow greater identification with alumni (the problem is the lack of a common brand and logo for them). The functioning of units responsible for relations with alumni at individual faculties and the involvement of academic staff in this activity is also considered beneficial. Universities seem to be aware of this relationship: only in $11 \%$ of those surveyed, academic staff are not involved in maintaining such relationships.

Figure 3. Survey question: Where is the unit responsible for relations with alumni situated in the organisational structure of the university?

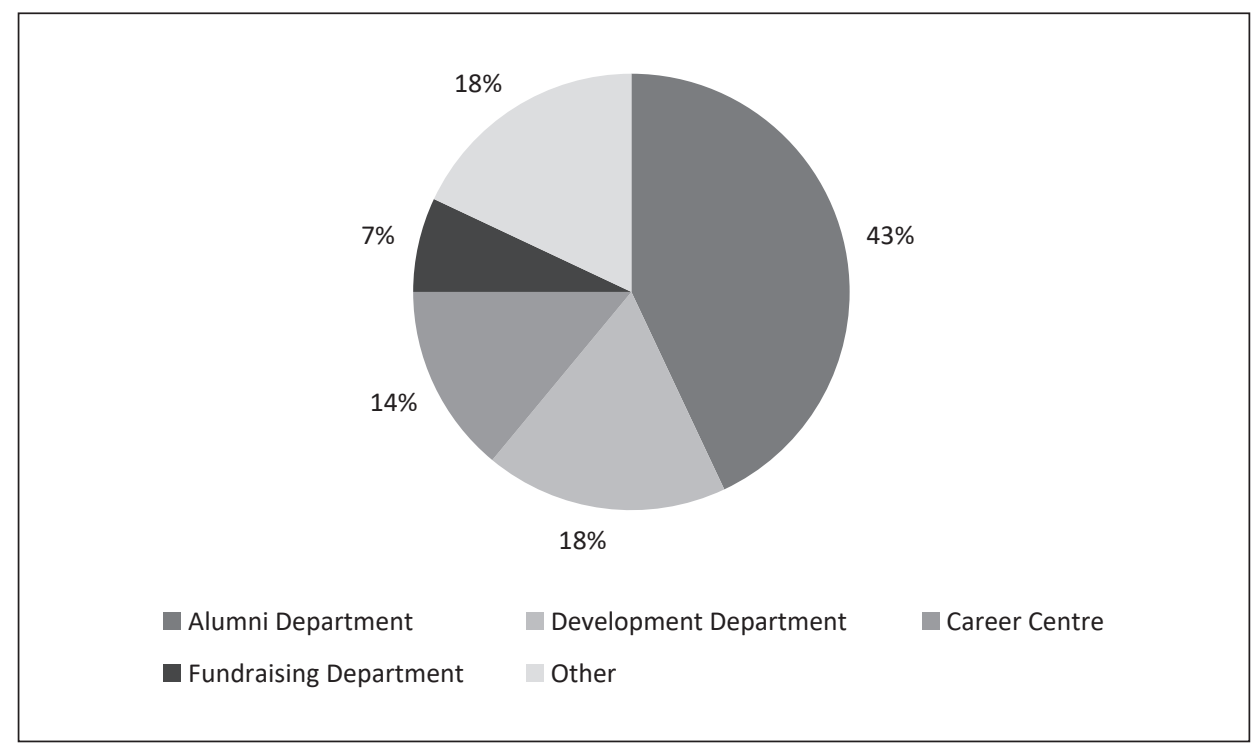

Source: author

9 The Alumni Office of the Warsaw School of Economics operated from May 2010 to November 2013. At the end of 2013, it was merged with the Office for Cooperation with Business and began to operate under the name of the Department of Cooperation with the External Environment. As a result of further changes, the team dealing with alumni relations worked at the Centre for External Relations and Technology Transfer, and now at the Centre of Career and Relations with Alumni. Apart from constant name changes, an additional threat seems to be employee turnover. None of the people who created the Alumni Office at the Warsaw School of Economics is still employed in this unit. This means losing valuable know-how. 
Universities often face a lack of up-to-date contact details, which limits the possibility of cooperation at the outset. In many countries, there is a poorly developed network of alumni and difficulties in its creation because there is no tradition of such cooperation. It is also difficult to maintain the involvement of alumni over the years. In time individuality and a weakening loyalty to the university appear (Kuźnar, Żukowska, 2018).

At most universities (90\%) there are alumni associations which are designed to integrate the alumni community. In some centres, they operate very dynamically, supporting universities in the implementation of their tasks. In many others, particularly in Poland, the activities of alumni associations and organisations leave much to be desired. A serious problem, identified by both the authors and other researchers (Eazorko, 2016), is the fact that the associations' offer is not adapted to the needs of younger alumni (unattractive websites, topics of meetings, a predominance of the elderly). Another problem is the large dispersion of organisations of alumni. At the Warsaw School of Economics, these are the SGH Alumni Association established in 1912, the Corporation of Foreign Trade (KHZ) founded in 1990, relatively young associations of alumni from individual MBA programs, postgraduate studies, international programs and an initiative of SGH from 2011, the SGH Alumni Club (Kuźnar, Żukowska, 2018). There are also countless alumni groups on social media. These organisations and groups cooperate to a small extent, seeking both a model of mutual relations and ways to attract new members to their ranks. This is a difficult task due to the lack of best practices and the institutional rigidity of the University's policy towards alumni as well as the lack of clearly defined goals of this cooperation.

\section{Summary}

The survey showed that universities are aware of the benefits of maintaining relationships with alumni. This also concerns the Warsaw School of Economics, but the quality of this cooperation is not satisfactory.

One of the problems is the lack of defining long-term goals and priorities for this cooperation. A big temptation, especially in the case of universities such as the Warsaw School of Economics, whose alumni belong to the financial elite of the society, is to raise funds as the primary goal. The results of the study, however, clearly show that fundraising is not the main goal at any university in the area of alumni relations. In continental Europe, the emphasis is on building correct relationships with students and alumni, and engaging them in various university projects, whereas raising funds from them is a side activity. This model is more suitable for Polish culture, because there is no tradition of transferring money to universities, and links with alumni are quite weak.

The other important problem is the number of graduate organisations and their low level of activity. Therefore, the priority should be to organise these relationships and outline the desired model of cooperation which will undergo further research.

The subject matter is extensive and provides an introduction to further study, including the collection of data from other economic universities in Poland and abroad, as well as the isolation of differentiating criteria and aggregation of universities according to these criteria to develop a model of cooperation between universities and alumni. 


\section{References}

Bryła, P., Jurczyk, T., Domański, T. (2013). Korzyści współpracy uczelni wyższych z otoczeniem gospodarczym - próba typologii. Marketing i Rynek, 4, 14-19.

Cannon, T. (2015). The importance of the alumni network. Retrieved from: https://www.redbrickresearch.com/2015/10/29/the-importance-of-the-alumni-network/

Coll, G., Tsao, J. (2005). To give or not to give: Factors determining alumni intent to make donations as a PR outcome. Journalism \& Mass Communication Educator, 59(4), 281-392.

Diagnoza potrzeb uczelni, studentów $i$ absolwentów w zakresie budowania trwałych relacji uczelnia student - absolwent opartych na wzajemnej wymianie wiedzy $i$ doświadczenia. Raport $z$ badania pogłębionego. (2013). Warszawa: Collegium Mazovia.

Daly, S. (2013). Philanthropy, the new professionals and higher education: the advent of Directors of Development and Alumni Relations. Journal of Higher Education Policy and Management, 35(1), 21-33. Retrieved from: http://dx.doi.org/10.1080/1360080X.2012.727701

Feudi, J.A., Clifford, P.J. (eds.) (2002). Alumni Clubs and Chapters. New York: CASE.

Harrison, W.B. (1995; 2019, 27 January). College Relations and Fund-Raising Expenditures: Influencing the Probability of Alumni Giving to Higher Education. Economics of Education Review, 14(1), 73-84. Retrieved from: https://doi.org/10.1016/0272-7757(94)00035-5

Hashim, N., Kee, P.Ch., Rahman, M. (2014). Attempt to Solving Situational Problem of Alumni Employability. Social Behavioral Science, 155, 380-385.

Kamiński, T. (2014). Uczelnie i absolwenci - dobre praktyki. Retrieved from: http://obywatelenauki.pl/ 2014/06/uczelnie-i-absolwenci-dobre-praktyki-tekst-tomasza-kaminskiego/

Kuźnar, A., Żukowska, J. (2018). Dobre praktyki w zakresie relacji szkół wyższych z absolwentami w świetle wyników badań empirycznych. Horyzonty Wychowania, 17(43), 157-165. doi: 10.17399/ HW.2018.174313

Levine, W. (2008). Communications and alumni relations: What is the correlation between an institution's communications vehicles and alumni annual giving?. International Journal of Educational Advancement, 8(3/4), 76-197.

Łazorko, K. (2016). Działania marketingowe ukierunkowane na absolwentów uczelni wyższych w Polsce - diagnoza głównych problemów. Handel Wewnętrzny, 2(361), 280-290.

Meer, J., Rosen, H.S. (2012). Does Generosity beget Generosity? Alumni giving and undergraduate financial aid. Economics of Education Review, 31, 870-907.

Murray, S. (no date). Learning from the American Fundraising Model: A European Perspective. King Baudouin Foundation United States. Retrieved from: https://kbfus.org/document/learning-american-fundraising-model-european-perspective/.

Muller, S., (1986). The Definition and Philosophy of Institutional Advancement. In: A.W. Rowland (ed.) Handbook on Institutional Advancement, $2^{\text {nd }}$ ed., San Francisco: Jossey-Bass.

Parsons, P., Wethington, D. (1996). Fund-raising appeals to alumni: Two experiments. Journalism \& Mass Communication Educator, 52(1), 44-50.

Pérez-Esparrells, C., Torre, E.M. (2012). The Challenge of Fundraising in Universities in Europe. International Journal of Higher Education, 1(2), 55-66.

Rissmeyer, P. (2010). Student Affairs and Alumni Relations. New Directions for Student Services, 130.

Stevick, T.R. (2010). Integrating Development, Alumni Relations, and Marketing for Fundraising Success, New Directions For Higher Education, 2010(149), 57-64. Retrieved from:http://dx.doi. org/10.1002/he.381

Studiuj praktycznie. (2018). Retrieved from: http://firma.sgh.waw.pl/pl/sp/Strony/default.aspx

Tett, G. (2012; 1 February). Charity begins with a tax break. Financial Times. Retrieved from: https:// www.ft.com/content/3b2b3bb2-9a3d-11e1-aa6d-00144feabdc0 
Andżelika Kuźnar, associate professor at the Institute of Economics of the International Collegium of World Economy of the Warsaw School of Economics. Her research interests focus on international economics. She conducts research on international trade (knowledge products, services, high technology goods), trade policy, economic integration and multinational companies. She is an author and co-author of textbooks, monographs and scientific articles, and an editor of academic monographs. In 2018, her book International trade in knowledge products was awarded the Prof. Edward Lipiński Prize by the Polish Economic Society. She lectures on international economics, multinational companies in the world economy, and services in the world economy. She is also a guest lecturer abroad (among others at Toulouse Business School, Tecnológico de Monterrey, Université Catholique de Lille). She was a Dekaban-Liddle Senior Fellowship scholar. She completed academic internships at the University of Oxford, University of Glasgow and University of Strathclyde.

ORCID: https://orcid.org/0000-0002-7042-4592

\section{Address:}

Szkoła Główna Handlowa w Warszawie

Kolegium Gospodarki Światowej

Instytut Ekonomii Międzynarodowej

al. Niepodległości 162

02-554 Warszawa, Poland

e-mail: andzelika.kuznar@sgh.waw.pl

Joanna Żukowska, associate professor at the Unit of Business Environment at the Institute of Enterprise at the Warsaw School of Economics. She holds the International Trainer Certificate in the field of training, learning and development issued by Edexcel and BTEC Professional Qualifications. Long-term coach. Head of Postgraduate Studies at the Academy of Professional Coach. Scientific supervisor of the Student Acceleration Scientific Association. She specializes in strategic personnel management, coaching, marketing communication, creating customer relations. Her main area of research interest is strategic personnel management, with particular emphasis on the theory and concepts for measuring the forms of employee competence development. She completed internships at the University of Bologna and the University of Fordham in New York. She has lectured at Toulouse Business School, ISCAP Porto, Vilnius Business School, ISCTE Lisbon, Budapest Business School, Universita Degli Studi di Firenze and others.

ORCID: https://orcid.org/0000-0001-9589-3056

\section{Address:}

Szkoła Główna Handlowa w Warszawie

Instytut Przedsiębiorstwa

al. Niepodległości 162

02-554 Warszawa, Polska

e-mail: jzukow@sgh.waw.pl 